\title{
Arterial System Endothelium
}

National Cancer Institute

\section{Source}

National Cancer Institute. Arterial System Endothelium. NCI Thesaurus. Code C49329.

The layer of cells that lines the arterial system. 